\title{
Liderlik ve Motivasyon: Kuramsal Bir Değerlendirme
}

\author{
S. Mustafa ÖNEN ${ }^{1}$ \\ Hasibe Gül KANAYRAN ${ }^{2}$
}

Öz: Günümüzde liderlik, belli amaç ve hedeflere ulaşmak için düzenli ve bilinçli olarak insanları etkileme ve yönlendirme yeteneği kabul edilmektedir. İyi bir lider, örgüt üyelerine sadece profesyonel başarıya ulaşma konusunda rehberlik eden değil; aynı zamanda onlara güven telkin eden, ikna kabiliyetini kullanan ve çoğunlukla onları motive eden bir kimse konumundadır. Bunun için çağdaş liderin; ileriyi görebilmesi, etkili ve verimli olması, etik ilke ve kurallarına uygun davranması yanında, her durumda güçlü bir uyum ve kendine güven duygusunu artıracak ve örgütte iletişim kanallarını açık tutacak şekilde çalışanların kendilerini geliştirmesine ve güven duygusunu artırmasına katkıda bulunmalıdır. Bu kapsamda çalışmanın amacı, örgütteki "liderlik" ve "motivasyon" kavramlarını kuramsal açıdan incelemek ve bu ikisi arasındaki ilişkiyi belli ölçüde irdelemektir. Çalışmada; önce liderliğin tanımı, türleri ve yaklaşımları olarak "Liderlik Kavramı ve Özellikleri” başlığı altında; sonra motivasyonun tanımı, türleri ve teorileri olarak ise "Motivasyon Kavramı ve Özellikleri” başlığı altında konular açıklanmıştır.

1 Doç. Dr. İnönü Üniversitesi, İ̇BF, Siyaset Bilimi ve Kamu Yönetimi Bölümü, mustafa. onen@inonu.edu.tr

2 Öğr. Gör. Gümüşhane Üniversitesi, İİBF, Siyaset Bilimi ve Kamu Yönetimi Bölümü, hgkanayran@gumushane.edu.tr 
Anahtar Kelimeler: Lider, Liderlik yaklaşımları, Motivasyon, Motivasyon teorileri

\section{Giriş}

Örgütsel politikalarla çalışanlar ile örgütün istek ve amaçlarının uyumlaştırılması, örgütte daha çok liderlik anlayışını ön plana çıkarmaktadır. Örgütte lider, kurum ile çalışanlar arasındaki bu dengenin kurulmasında ve çalışanların isteklendirilmesinde önemli roller üstlenmektedir. Lider; örgütte çalışanları motive ederek örgütsel verimliliği artırmaktan sorumlu kimsedir. Örgütün başarısının çalışanların başarısından geçebileceği düşüncesi, lider tarafından kesinlikle göz ardı edilmemesi gerekmektedir.

Motivasyon, insan ilişkilerine yön veren önemli bir olgu sayılmaktadır. Liderliğin belki de özünü, kendisine tabi olanların çabalarını örgütsel amaçlar doğrultusunda yönlendirmekten geçmektedir. Çalışanların istekli olması, işlerini benimsemeleri ve çaba göstermeleri, liderin onları motive etmeleri sayesinde mümkün olacaktır. Liderin temel görevi, çalışanların isteklerini sürekli ve canlı tutmak; bunun için örgütte iletişim kanallarını açık tutmak, onların kendilerini gerçekleştirmesine imkan tanımak ve güven duygusunu geliştirmektir.

$\mathrm{Bu}$ açıdan lider, örgüt çalışanlarının motive edilmesinde kilit bir rol ve fonksiyon üstlenmektedir. İşte bu çalışmanın amacı, liderlik ve motivasyon konularını kuramsal açıdan incelemek; bu iki kavram arasındaki ilişkiyi belirli ölçüde irdelemektir. Bu nedenle çalışmada konular; sırasıyla liderliğin tanımı, türleri, yöneticilikten ayrıldığı farklılıklar ve yaklaşımları olarak "Liderlik Kavramı ve Özellikleri” başlığ altında; motivasyonun tanımı, temel bileşenleri ve teorileri olarak ise, "Motivasyon Kavramı ve Özellikleri” başlığı altında açıklanmıştır. Çalışma, liderlik ve motivasyon arasındaki ilişkilerin değerlendirilmesi konusu ile tamamlanmıştır.

\section{Liderlik Kavramı ve Özellikleri}

Lider kelimesi 1755 yılında yayınlanan bir İngilizce sözlüğünde önde giden kimse; 1828 yılında hazırlanan Webster Amerikan sözlüğünde, 
lider olacak kimsenin özellikleri yönünde; Oxford İngilizce sözlüğünde ise, ilk olarak 1976 yılında insanlara liderlik edilmesi ve etkileme sanatı şeklinde tanımlanmıştır (Rost, 1993: 38-42). Lider sözcüğü, Türkçede “önder” karşılığında da kullanılmaktadır. Ancak "önder" kelimesi; ne literatürde ne de uygulamada pek fazla tercih edilmemektedir.

Lider; örgütsel hedeflere ulaşabilmek için belli bir durum, zaman ve koşullar altında insanları teşvik eden, onlara deneyimlerini aktaran ve örgüt üyelerinin yönetimden memnun kalmalarını sağlayan kişi sayılırken; liderlik ise, örgütsel amaçların gerçekleştirilebilmesinde grupsal aktiviteleri etkileme süreci (Werner, 1993: 17) olarak kabul edilmektedir. Bir başka anlamda liderlik, hedeflenenlerin gerçekleştirilebilmesi için belli bir amaç doğrultusunda örgütlenmiş üyeleri elde etme çabası (Vecchio, 1991: 202) şeklinde açıklanmaktadır.

Lider; geleceğe umutla ve iyimserlikle bakmalı, gereken durumlarda risk alabilmeli, astlarına karşı güven duymalı, ortamı iyi analiz edebilmeli, hedeflerini ve standartlarını ortaya koyabilmeli, katı denetimden kaçınarak astlarına özgürce davranabilecekleri bir ortam yaratmalı ve en önemlisi de yönetmek özelliğinden ziyade liderlik yeteneğine sahip olması gereklidir (Wadsworth, 1999: 16-17). Bu sayede, liderin kendini gruba kabul ettirmesi, düşüncelerini karşıdakine benimsetmesi kolaylaşır. Zaten liderin en temel özelliği, sezgisi güçlü, dürüst, saygın, başkalarına değer verip düşüncelerini dikkate alan ve vizyoner kişiliğinin ön plana çıkmasıdır.

Liderlik ve yöneticilik, her ne kadar birbirlerine benzer kavramlarmış gibi gözükseler de, aslında farklı anlamlara gelmektedir. Liderlik, belli koşullara göre, bireysel ve grupsal amaçlara yönelik kişinin diğer insanları etki altında alması olarak (Serinkan, 2008: 150-151); öngörülen amaçların gerçekleştirilmesi için örgüt üyelerini etkileme ve yürekten çalışmalarını sağlayabilme yeteneği (Ertürk, 2000: 151) olarak sayılırken; yöneticilik ise, birtakım amaçların gerçekleştirilmesi için bir araya gelmiş insanların bu amaçlara ulaşmak için belli bir ahenk ve uyum içinde çalıştırılması (Eren, 1993: 6) olarak ifade edilmektedir. Lider, örgütün insan kaynağ 
sağlamak için gerekirse olağanüstü yeteneklerini ve güçlerini ortaya koyarken; oysa yönetici, önceden sınırları çizilmiş belli kurallar ve standartlar içinde örgütsel amaçlara ulaşmak için daha çok planlama, örgütleme, yöneltme, eşgüdüm ve denetim fonksiyonlarını kullanmaktadır.

\section{Liderlik Türleri}

Çok sayıda liderlik türü bulunmaktadır. Bunların başlıcası şunlardır:

(1) Otokratik Liderlik: Bu tip lider, kendine tabi olanlara bask1 uygulama eğilimiyle tiranlara benzer davranış gösterir; muhalefetten hoşlanmaz ve katı kurallarla belli davranış kalıplarını uygular (Yeo, 2006: 65). Otokratik lider, karar almada sadece kendisi yetkilidir ve sahip olduğu gücü diğerlerine aktarmamaktadır. Otokratik liderin grup üyelerini motive etmesi genellikle önceden sahip olduğun gücün kullanılmasına (Sargut, 2001: 234) dayanmaktadır. Yönetim, karar alma ve uygulama yetkisi, otokratik lidere aittir. Bu tarz liderlik, daha çok otokratik ve bürokratik yönetime sahip toplumlar için geçerlidir.

(2) Tam Serbesti Tanıyan (Laissez-Faire) Liderlik: Grup üyelerinin ve lider izleyicilerinin kendilerini yetiştirmesi ve sorunlara karşı çözümün bulunması ile ilgili güdülenmesi söz konusudur. Gereken durumlarda kişiler istedikleri kişi ile grup oluşturarak sorunlarını çözebilir, yeni fikirler edinebilir ve makul gördüğü kararları alabilmektedir. Bu liderlik tarzında liderin esas görevi kaynak sağlamaktır (Türkmen, 1999: 63). Lider, örgütün geleceği açısından önem taşıyan bütün sorumluluğu üyelere bırakırken; öncelikle bu sorumluluğu üstlenebilecek kişiliğe ve yeteneğe sahip bireylerin olması gerekir.

(3) Katılımo veya Demokratik Liderlik: Bu liderlik türünde, lider ve takipçileri merkezi otoriteden ziyade sosyal bir grup olarak hareket ederler (Newstorm ve Davis, 1993: 227). Demokratik lider, insan ilişkilerine büyük önem vererek çalışanları sürekli destekler ve onları motive eder. Karar alım sürecine onları dahil eder, astları üzerinde baskı kurmadıkları için belirlenmiş amaç doğrultusunda ilerler, hem yetkileri hem de çalışanları onlara destek olur (Güney, 1997: 213). 
(4) Karizmatik Liderlik: Lider; genellikle kriz zamanlarında kendini gösteren olağanüstü niteliklere ve güçlü kişilik özelliklerine sahiptir. Bu tip liderlikte lider, genelde özgüven sahibi, cesaretli, çalışanları üzerinde hayranlık uyandıran, ikna kabiliyeti ve motive etme gücü fazla olma gibi özelliklere sahiptir (Çelik ve Sünbül, 2008: 52). İzleyenleri arasında körü körüne bir bağlılık yaratmaktan ziyade toplumsallaştırılmış vizyon sahibi örgütlerin ortaya çıkmasını sağlar (Choi, 2006: 8). Ülkemizde karizmatik lidere en güzel örnek olarak Atatürk verilebilir.

(5) Dönüşümcü ve Etkileşimci Liderlik: Liderin, çalışanlarıyla birlikte iktisadi, siyasi ve psikolojik etkilerini değişime bağlı olarak bir ilişki içersine girmesidir. Lider, izleyicilerini ödüllendirme klasik motive edici araçların yanı sıra, onların motivasyon düzeyini artırabilecek diyalogu sağlama içindedir (Burns, 1979: 19-20). Dönüşümcü ve karizmatik lider, izleyicilerine iyimser bir vizyon veya ideal gelecek sağlayabilir ise, izleyicilerin çıktı ve pozitif geri beslemesi konusunda daha duyarlı olması muhtemeldir (Kark ve Dijk, 2007: 516).

(6) Vizyoner Liderlik: Bu tip lider, örgüt üyelerini ve izleyicilerini etkileyerek harekete geçirme, geleceğe dönük bir şekilde somut ve ulaşlabilecek amaçları belirleyebilme yeteneğine sahiptir (Erdoğan, 2002: 48). Vizyoner lider, geleceği gerçek anlamda görebilmekte ve gelecekte ulaşmak istediği konuma ulaşabilmek için çalışanları ile birlikte hareket edebilmektedir (Doğan, 2007: 97). Liderin, karşılaşabileceği olumsuzlukları önceden görüp üstesinden gelebilmesi önemli bir üstün yanıdır.

(7) Süper Liderlik: Süper liderlik, kendine yeten liderlikten farklı olarak zamanla "süper" kavramıla geliştirilerek örgüt üyelerinin genellikle görevlendirildiği ve yetkilendirildiği üstün bir gücün transferi olarak tanımlanmaktadır (Müller vd., 2013: 805). Süper liderlikte işgörenler lidere bağımlı durumdan bağımsız duruma geçmişlerdir (Çırpan, 1999: 8). Süper liderlik yaklaşımında liderlik, lider ile izleyiciler arasında paylaşılan bir süreçtir. 


\section{Liderlik Yaklașımları}

Liderlik konusundaki yaklaşımları; başlıca üç başlık altında toplamak mümkündür.

(1) Özellikler Yaklaşımı: Bu yaklaşım, genel olarak lideri tanımlayan ve açıklayan en temel yaklaşım olup, liderin sahip olduğu özelliklerin onu üstün kıldığı esasına dayanmaktadır (Fındıkçı, 2009: 61). "Özellikler Yaklaşımı”, liderlikle ilgili geliştirilen ilk teori sayılıp, liderin sahip olduğu fiziksel, sosyal ve kişisel özellikler yaklaşımının odak noktasını oluşturmaktadır (Bolat v.d., 2008: 172). Bazı insanların doğuştan lider olduğu ve bu liderliğin de diğerlerinden ayrılan birtakım fiziksel özellikler ve yetenekler barındırdığı esasına dayanmaktadır (Koçel, 2003: 588). “Özellikler Yaklaşımı”na göre, liderin taşıması gereken özellikleri aşağıdaki gibi sıralanabilir (Yukl, 1991: 183):

- Üstün fiziki özelliklere sahip bulunma.

- Bilgi ve onu kullanma zeka ve yeteneği olma.

- Yaratıcı ve dürüst bir kişiliğin olması.

- İşi Başarma ve sorumluluk alma güdüsüne sahip olma.

- Sosyal ve katılımcı bir ruha sahip olma.

(2) Davranışsal Yaklaşım: Bu yaklaşıma göre, liderlerin başarılı ve etkin olmasını sağlayan esas unsur; liderlikle ilgili olarak sergilemiş olduğu davranışlarıdır. Liderin astlarıyla ilgili olarak, yetkilerini devredip devretmediği, liderin uygulama kapsamındaki her türden davranışı liderin iletişim süreci içindeki etkinliğini belirleyen önemli faktörler kabul edilmektedir. Bu yaklaşımın geliştirilmesinde pratik ve teorik araştırmaların önemli etkisi bulunmaktadır. İlgili araştırmalar sonucunda birçok liderlik tarzı ortaya çıkmış ve bu liderlik tarzları da incelenmiştir (Çetin ve Beceren, 2007: 126-127). ${ }^{3}$

3 Söz konusu liderlikle ilgili davranışların araştırılmasında bazıları aşağıdaki gibi sıralanabilir (Bakan ve Büyükbeşe, 2010: 74-75):

- Ohio Devlet Üniversitesi Modelinde, kişiyi ve yapıyı esas alan davranış türü öngörülmüştür.

- Michigan Üniversitesi Araştırmasında, iş ve birey odaklı davranış belirlenmiştir. 
(3) Durumsallık Yaklaşımı: Bu yaklaşıma göre, değişik koşullar farklı liderlik türlerini gerektirebilir. Farklı durum ve koşullar farklı liderlik tarzlarını ortaya çıkarmaktadır. Liderin görevine yönelik göstermiş olduğu davranışlar ile karşılıklı ilişkilerin gösterdiği davranışlar, örgüt üyelerinin sergilediği davranışları ve hazır olma seviyesi arasındaki karşılıklı etkileme birbirine bağlıdır. "Durumsallık Yaklaşımı" arasında şu teoriler gösterilebilir (Dilts, 1996: 203): Fiedler'e ait Durumsallık Teorisi, Ardışık Teori, Yol Amaç Teorisi, Normatif Teori, Durumsallık Teori ve Reddi’ne ait Üç Boyutlu Liderlik Teorisidir.

$\mathrm{Bu}$ teorilerin temel özelliği tek bir liderlik türünün her zaman söz konusu olamayacağı, bu nedenle bazen görev ağırlıklı liderlik anlayışı, bazen de tam tersine ilişki ağırlıklı liderlik anlayışının bulunabileceği savunulmaktadır (Çağlar, 2004: 10). Ancak bütün teorilerin; aslında liderin sahip olması gereken yetki ve yeteneklerin neler olması gerektiği konusunda daha çok birleştikleri anlaşılmaktadır.

\section{Motivasyon Kavramı ve Özellikleri}

Motivasyon Latincede "hareket etmek" anlamını taşıyan "movere" kelimesinden türemiştir (Adair, 2003: 9). Motivasyon kelimesi; güdüleme ve harekete geçirici gibi kavramlar karşılığında da kullanılmaktadır. Motivasyonun belli bir hareketin başlatılması, devam ettirilmesi ve yapıcı olarak yönlendirilmesi şeklinde özellikleri vardır (Eren, 2000: 474). Motivasyon, çalışanın bireysel ihtiyacının giderilmesiyle örgütün amaçlarına ulaşmada gerekli üst düzey çabanın gösterilmesidir (Robbins,

- Harvard Üniversitesi Araştırmasında, sosyo-duygusal ve işşeklinde iki temel liderlik davranışı esas alınmıştır.

- Blake ve Mouton Yönetim Tarzı Matriks Modelinde, üretime yönelik ve kişiler arası ilişkilere yönelme şeklinde açıklanmıştır.

- X ve Y Yaklaşımlarında, kişilerin tembel, çalışmayan, sorumluluk almayan ve yeniliğe direnç gösteren anlayışına dayanan $X$; kişilerin çalışkan, üretken ve yenilikçi olma anlayışına dayanan Y kuramı kabul edilmiştir.

- Yukl'un Davranış Modellerinde liderlik ayrılık ve çoklu-bağlanma esasında ele alınmıştır.

- Rensis Likert'in Modelinde, istismarcı, koruyucu, danışan ve katılmalı otoriter tarzları incelenmiştir. 
1996: 212). Motivasyon en genel anlamda; insan davranışlarının fizyolojik veya psikolojik yöndeki eksik kalan bir ihtiyacın harekete geçirilmesini (Luthans, 1992: 147) ifade etmektedir.

Bir kaynakta motivasyon; örgütsel hedeflere ulaşmak için insanın, fiziksel ve psikolojik yöndeki ihtiyaçlarını karşılaması için kendi mevcudiyetinin vermiş olduğu şartlanmayı gösteren istekliliğidir (De Cenzo ve Robbins, 1996: 296-297). Motivasyon sayesinde birey, kendi çaba ve faaliyetleri örgütsel amaçlar doğrultusunda yönlendirilmektedir. Motivasyon sayesinde örgütün verimliliği artarken; çalışanların doyum düzeyi de artmış olur. Örgütlerin başarısı çalışanlarına bağlı olduğu için kuruma başarılı ve yetenekli elemanların alınmasını sağlar.

Motivasyonun örgütsel hedefler, bireysel ihtiyaçlar ve efor olmak üzere üç temel bileşeni bulunmaktadır. Motivasyonda temel amaçlardan biri örgütsel hedeflerin gerçekleştirilebilmesi için kişiyi işine motive edebilmektir. Motivasyonun örgüt yararına kullanılabilmesi ve yönetsel başarıya katkıda bulunabilmesi için kişinin örgütsel hedeflere yönlendirilmesi gerekmektedir (Şimşek v.d., 1998: 98). Bunun için bireysel ihtiyaçların tatmin edilmesi gerekmektedir. Çalışanların beklenti ve gereksinmeleri karşılanmadıkça, örgütte dengesizliğin ve gerilimin (Eren, 1993: 318-319) azaltılması mümkün olmayacaktır. Motivasyon ile performans ve olumlu iş tutumları arasında güçlü bir ilişki vardır. Motive edilen kişilerin işe bağlılıkları arttığı gibi performansları da yüksek olur.

\section{Motivasyon Teorileri}

Motivasyon ile ilgili teoriler, "kapsam" ve "süreç" teorileri olmak üzere iki gruba ayırmak mümkündür. Kapsam teorileri, içe dönük etkenlere öncelik verir iken; süreç teorileri ise, dışa dönük etkenlere öncelikle yer verilmektedir. Liderlerin çalışanları ve örgütü etkili bir şekilde yönetebilmeleri için bu teoriler oldukça önemlidir. Çünkü her bir teori lider için bir 1şık kaynağı olabilir. Liderler için büyük bir önem taşıyan motivasyon teorileri aşağıda alt başlıklar halinde ayrıntılı olarak incelenmiştir. 
(1) Kapsam Teorileri: Bu teoriler; "İhtiyaçlar Hiyerarşisi Teorisi”, "Varolma-İlişki Kurma-Gelişme İhtiyaçları Teorisi”, "Çift Faktör Teorisi” ve "Başarı İhtiyacı Teorisi” olmak üzere dörde ayrılmaktadır.

a) İhtiyaçlar Hiyerarşisi Teorisi : A. Maslow tarafından ortaya atılmış en popüler olan motivasyon teorilerindendir. Maslow'un ihtiyaçlar teorisine göre, bireyin alt basamaktaki bir gereksinimi giderilmedikçe, bireyin daha üst gereksinmesini karşılaması söz konusu olmayacaktır (Akat v.d., 1994: 210). Maslow'in ortaya koyduğu bu ihtiyaçlar; temel ihtiyaçları gösteren fizyolojik ihtiyaçlardan, güvenlik ihtiyaçlarına, sosyal ihtiyaçlara, değer-saygınlık (kendini gösterme) ihtiyacına ve kendini gerçekleştirme ihtiyacına doğru aşağıdan yukarıya dönük olmak üzere beşli bir kademe içinde incelenebilir. ${ }^{4}$

b) Varolma-İlişki Kurma-Gelişme İhtiyaçları Teorisi: C. Alderfer tarafından 1970'li yılların başında Maslow'un ihtiyaçlar teorisi sınıflamasını basitleştirmesi ile birlikte geliştirmiş olduğu bir motivasyon yaklaşımıdır. Bu teoriye göre, ihtiyaç sıralaması daha basit ve Maslow'un teorisindeki ihtiyaç sıralaması esas alınmaktadır (Koçel, 2003: 643). Maslow'dan ayrı bir şekilde, bu teoriyle örgütlerdeki insan gereksinmelerine yönelik bir uyarlanma yapılmaya çalışılmıştır (Porter v.d., 2003: 8). Alderfer'e göre ihtiyaçlar, üçe ayrılmıştır (Efil, 2006: 158-159): (1) Fizyolojik ve güvenlik ihtiyaçları gibi varolan ihtiyaçlar, (2) Bir arada bulunma ve sosyal ilişki içinde olma ihtiyacı, (3) Bireyin kendi kendisini geliştirmesi ihtiyacı.

c) Çift Faktör Teorisi: Frederick Hersberg'in gerçekleştirdiği araştırmalarla birlikte geliştirmiş olduğu "Çift Faktör Teorisi", işyerindeki iki türlü etmenin iş görenin güdülemesini etkilemesidir (Yüksel, 2000: 139): $\mathrm{Bu}$ etmenlerden biri içsel, diğeri ise dışsal etmenlerdir.

4 Bu ihtiyaçlar aşağıdaki gibidir (Efil, $2006: 153$ ):

- Fizyolojik İhtiyaçlar: Yaşamak için gerekli olan temel ihtiyaçlardır.

- Güvenlik İhtiyaçları: Risklere karşı kendini korumaya dönük ihtiyaçlardır.

- Sosyal İhtiyaçlar: Bir arada bulunmaktan kaynaklanan sosyal yönü ağır basan ihtiyaçlardır.

- Saygınlık Kazanma İhtiyacı: Kişinin statü ve itibar görmek istemesi ihtiyacıdır.

- Kendini Gösterme İhtiyacı: Kişinin sahip olduğu yetenek ve hünerleri gerçekleştirme ihtiyacıdır. 
d) Başarı İhtiyacı Teorisi (David Mcclelland): Bu teori ilk olarak Henry Murray tarafından ortaya konmuş ancak 1960’lı yılların başından itibaren David McClelland tarafından geliştirilmiştir. McClelland, ihtiyaçların öğrenmeyle kazanıldığını ileri sürmüştür. Bireysel davranışlar ile çevresel etmenlerin biraraya nasıl getirileceği konusu üzerinde durulmuştur (Can, 1999: 179).

(2) Süreç Teorileri: Bu teoriler, genel anlamda herhangi bir davranışın nasıl başladığı, nasıl yönlendirildiği ve nasıl sürdürüldüğünü açıklamaktadır. Bu teoriler, davranışların altında yatan birtakım psikolojik etkilere odaklanarak kişilerin karar alma sisteminin işleyişini açıklamaya ağırlık vermektedir (Dinçer ve Fidan, 1996: 312). Süreç teorileri: Şartlandırma ve Pekiştirme Teorisi, Eşitlik Teorisi, Beklenti Teorisi, Geliştirilmiş Beklenti Teorisi ve Amaç Teorisi olmak üzere beşe ayrılmaktadır.

a) Şartlandırma ve Pekiştirme Teorisi: Şartlandırma teorisi kendi içinde «klasik» ve «sonuçsal» olarak ikiye ayrılır. Klasik şartlandırmada özellikle Pavlov tarafından köpekler üzerinde yapılan deneylere dayanmıştır. Pavlov`dan esinlenen Skinner ise yeni bir motivasyon teorisi olarak sonuçsal şartlandırma türünü geliştirmiştir. Sonuçsal şartlandırmanın ana fikri şudur (Koçel, 2001: 518): İnsanlar belli birtakım amaçları gerçekleştirmek, var olan ihtiyaçlarını karşılamak veya önceki şartlanmalar nedeniyle birtakım davranışlarda bulunurlar.

b) Eşitlik Teorisi : 1960’lı yıllarda Stacy J. Adams tarafından ortaya konan eşitlik teorisine göre motivasyonun temelinde insanların kendilerine eşit davranılması isteği yatmaktadır. Bu teoriye göre kişi, kendi kurumundan başka bir kişiyle kendini karşılaştırması ve algılamış olduğu durumun ortaya konmasıdır (Efil, 2006: 157). Diğer deyişle, insanlar genelde göstermiş oldukları performans karşıllı̆̆ında kendilerine eşit davranıldığını görmek isterler ve bunu gördükçe de motive olurlar.

c) Beklenti Teorisi: 1964 yılında Victor Vroom tarafından ortaya konulan “Beklenti Teorisi”ne göre, kişilerden kaynaklanan özelliklerin motivasyondaki önemi incelenir. Vroom, değer, araçsallık ve beklenti olmak üzere üç faktörün motivasyonun bir ürünü olduğunu savunur. Bunlar aşağıdaki gibi sıralanabilir (Newstrom ve Davis, 1993: 148): 
- Değer (Valence): Örgüt üyelerinin kazanması olası getirilere ve ödüllere verdikleri değerdir. Ödüllere ve getirilere atfedilen değer kişiden kişiye değişmektedir.

- Araçsallık (Instrumentality): Kişilerin liderler tarafından verilen görevleri ve sorumlulukları yerine getirmeleri durumunda vaat edilen ödülü alacaklarına olan inançlarını ifade eder.

- Beklenti (Expectancy): Bireylerin göstermiş olduğu çaba sonucunda yüklenilen görev ve sorumlulukların tamamlanabileceğine olan inancin kuvvet derecesidir.

Beklenti teorisi, kişinin çabası ve performansı sonucunda elde edilecek getiriler arasındaki ilişkiye dayanmaktadır. İlgili süreçte en önemli unsur, bireylerin motive olmalarından sonra sergileyecekleri davranıştan önce oluşturmuş oldukları beklenti duygularıdır. Bunlar efor-performans beklentisi ile performans-getiri beklentisi şeklinde ortaya çımaktadır (Bateman ve Zeithaml, 1990: 531-532).

d) Geliştirilmiş Beklenti Teorisi: Bu teori, örgütsel düzeyde geliştirilmiş ve bireylerin göstermiş oldukları çabalar sonucunda elde ettikleri ödüllerini başka bireylerle karşılaştırmasıdır. Gösterilen başarıyla ilgisi bulunmayan incelemeye tabi tutulmuşsa, doyumlulukları olumsuz yönde etkilenir (Eren, 1993: 397).

Görev, yetki ve sorumlulukların açıkça ortaya konmadığı örgütteki işgörenlerin beklenilen davranışları sergilemesindeki güçlerin azaldığ ve motivasyonu etkileyen rol çatışmalarının yaşandığı belirtilmektedir. Bu nedenle liderlerin motivasyona olumlu katkıda bulunmasını sağlayacak örgüt ikliminin oluşturulması gerekmektedir. Motivasyon elde edilen tatmin ve gösterilen performansa eşit olmayıp, performansla tatmin değil, aksine tatmine neden olan performans olmaktadır (Baysal ve Tekarslan, 1996: 118).

e) Amaç Teorisi : Edwin Locke tarafından 1968 yılında geliştirilen "Amaç Teorisi"nde liderlerin ve izleyicilerin belirli bir hedefin saptanması esasına dayanır. Bireysel amaçların saptanması motivasyon üzerinde yapıcı bir katkıda bulunduğu savunulmaktadır. Bu teoriye göre 
değer yargılarının insanların kazanılması doğrultusunda davranışlara yön verilmesidir. Bireylerin amaçlara ulaşmasalar da bu amaçların fikir birliğine varılmasıdır. Ayrıca ilgili geri besleme oluşabilmektedir (Luthans, 1992: 194).

\section{Liderlik ve Motivasyon Arasındaki İlişki}

Liderlik, bireylerin hareketleri veya davranışları üzerindeki etkileme sanatı iken; lider, kendine özgü isteklerini bireylere kabul ve itaat duygusuyla kabul ettirmesidir. Liderliğin bir kısmı genellikle doğuştan gelmesine rağmen daha sonra eğitim ile de geliştirilebilir. Bu özelliklerin yanı sıra liderde motive edici özelliklerin bulunması gerekir. Çünkü motivasyonun, çalışanın örgütsel amaçlara uyum düzeyini artırırken, iş tatmininin oluşması gibi olumlu katkıları bulunmaktadır (Ünlü vd., 2013: 105). İdeal bir motivasyon örgütte bütün çalışanların bir arada işbirliğine dayalı birlikte çalışma ruhuna katkı sağlamaktadır.

Örgütlerin misyonlarını gerçekleştirerek vizyonlarına ulaşabilmelerinde motivasyonun önemli bir rolü bulunmaktadır. Örgütte çalışanların motive edilmesi örgütsel verimliliği ve başarıyı sağlamaktadır (Serinkan, 2008: 163). Liderin, örgütün amaçları etrafında toplanan ve kişisel özellikleri bulunan çalışanlara, baskı altında kalmamaları ve liderin dayatması olmadan hareketlerini serbestçe yapabilme ve düşünme durumu sağlayabilmelidir (Bolat v.d., 2008: 170). Lider tarafından hazırlanan rahat ve baskıcı olmayan bir ortamın çalışanları motive etmesi muhtemeldir. Lider çalışanları bekledikleri ve arzu ettikleri performansı gerçekleştirmeleri konusunda olumlu bir biçimde teşvik edebilmelidir (Sezici, 2008: 169).

Herzberg'e göre kişiye doyum sağlayan faktörlerin başında; kişinin başarısı, tanınması, sorumluluğu, terfisi ve işin kendisi şeklindeki özellikler gelmektedir. Çalışanların yapmış oldukları işe, sıralanan bu özelliklerden hangisinin kendilerine kazanç sağladığına inanılıyorsa, çalışanlar yaptıkları işten o kadar tatmin olacaklardır. Çalışma koşulları, ücret ve arkadaşlık ilişkileri gibi faktörler örgütte hijyen faktörleri olup, bu da her zaman çalışanlar üzerinde olumlu bir etki bırakmayabilir. 
Hatta bu faktörlerin, motivatör olduğunu söylemek bile zordur (Akçadağ ve Özdemir, 2005: 172). Başka araştırmalarla da çalışanların motivasyon düzeylerine etki eden faktörler incelenmiştir (DeMato, 2001: 23-24; Hageman, 1997: 41; Oral, 1999: 161-168; Purcell, 2003: 97-101).

Motivasyon ile sağlanmak istenen hedef, örgütün amaçları yönünde çalışanların mümkün olduğunca gerekli çabayı göstermesini oluşturmaktır (Gürüz ve Gürel, 2006: 290). Liderler örgütsel başarıyı artırabilmek için motivasyonun önemini kavramalı ve bu konuya gerektiği ölçüde ağırlık vermelidir. Liderin çalışanları örgütün amaçları doğrultusunda yönlendirilmesine ve örgütte yaratılmak istenen hedefler doğrultusunda bir araya gelmesine bağlıdır. Motivasyon ile performans birbiriyle ilgili olan iki kavramdır. Çalışanlar sahip oldukları bilgilerini, yeteneklerini ve çabalarını örgütün değişimini anlayacak veya idrak edecek yönde gerçekleştirirlerse başarı artacaktır (Koçel, 2003: 633). Motivasyonla çalışanların kapasitesi geliştirilerek ilgili fonksiyonların ve her kademedeki takım ruhu ile sorumluluk duygusu artırılmak istenir (Eren, 2004: 164). Liderin motivasyonu sağlamada çalışanları cesaretlendirmesi ve özendirmesi lazımdır.

Liderin başarısı öncelikle örgütün insan kaynağının motive olmasına bağlıdır. Bunu gerçekleştirebilmesi için öncelikle motivasyon kavramını ve özelliklerini bilmelidirler. Bunun için lider, örgütün insan kaynağının kişisel özellikleri ile birlikte işle ilgili özelliklerinin çevresel özellikleri ve iş görenlerin davranışını nasıl etkilediğini sistematik olarak analiz etmeli, motivasyona ilişkin ortaya çıkan dinamik bir içsel durum olduğunu ve kişilerin motivasyonunun belli değişimlerden etkilendiğini bilmelidir (Wiley, 1997: 263).

Liderin çalışma arkadaşlarının hedeflerinden sapmamaları, morallerini yüksek tutmaları, çalışma isteklerini kaybetmemeleri ve örgüte beklenen katkıyı yapabilmeleri, yönetim tarafından gerçekleştirilebilecek etkin bir liderlik ile mümkündür Lider, öncelikle izleyicilerinin arkasında olmalı ve bunu onlara hissettirerek onları motive ederek verimliliklerini ve sorumluluklarını artırarak çalışma kültürüne katkıda bulunacaktır (Ünlü v.d., 2013: 111). Değiş̧imin, yeniliği takip etmesi ve 
liderin ise, çalışanları özendirmeye gerekli araçları uygulamaya aktarması gerekir (Eren, 2003: 566-567). Özendirici araçların çalışanlara uygun yönde ve onları teşvik edici tarzda bulunması şarttır.

Kişinin sergilemiş olduğu davranışla motivasyon arasında yakın ilişki vardır. Bu nedenle liderin, çalışanların davranışlarını yorumlaması ve buna dönük modelleri ve uygulamaları devreye aktarabilmelidir. Motivasyonun örgütte liderin tamamlayıcısı olarak, çalışanların başarısı üzerinde olumlu bir etki bırakacaktır. Ancak liderlerin insanları motive etme yöntemleri birbirinden farklılık arz etmektedir. Bazı liderler izleyicilerini ödüllendirerek olumlu liderlik yaklaşımını kullanırken; bazı liderler ise, cezalandırma yöntemini kullanarak olumsuz liderlik yaklaşımını sergilemektedir. Ödüllendirme ve cezalandırmanın ağırlık derecesi uygulanan liderlik yaklaşımının ağırlı̆̆ını ortaya koymaktadır (Davis, 1988: 149). Liderliğin, örgütün iş doyumunu ve başarısını artırıcı etkisi söz konusuysa, bunun örgüt üzerindeki yapıcı ve olumlu sonucu olacaktır.

Motivasyon, geniş kapsamı ve anlamıyla çalışanların temel fizyolojik ihtiyaçlarını gerçekleştirmesi, bir gruba ait olması veya faydalı bulunması isteği örgütte yer alırken; diğer yandan ise, örgütün amaçlarına en iyi şekilde ulaşılmak istenmesi arzusunu tetiklemektedir. Örgütte liderlerin genellikle iki asli amacından söz edilebilir. Birincisi, örgütteki beşeri kaynakların örgütsel amaçlar yönünde yönlendirilmesi, onlar1 örgütsel hedef ve amaçlar doğrultusunda en etkin bir performans düzeyinin ortaya konmasıdır. İkincisi ise, beşeri kaynakların bireysel amaçları, ihtiyaçları ve beklentileri gerçekleştirmeyi sağlayacak iş ortamının kurulmasıdır (Ünlü v.d., 2013: 102).

Motivasyon ile liderin amaçları bazen birbiriyle kesişebilir. Liderin örgütte çalışanların motivasyonunu artırarak onları daha etkin ve verimli hale getirmesinde anahtar bir rol oynamaktadır. Örgütsel amaçlara kendini adamış bir lider her şeyden önce yönetim fonksiyonlarını kullanırken çalışanların örgütsel amaçlara tam olarak kanalize olması için çok iyi bir şekilde motive edilmeleri gerekmektedir. 
Lider, motivasyon planını yaparken bu planı birtakım özendirme araçlarına dayanarak uyguladığında daha başarılı olmaktadır. Lider; çalışanlara yüksek gelir elde etme imkânı, ekonomik, sosyal ve yarg1sal güvence, bireylere yeteneklerini geliştirme, yükselme, ilerleme ve başarı sağlama imkânı, çalışanların yaptıkları işi çekici bulmalarını sağlamak için çalışanların yaratıcılık yeteneklerini gösterme fırsatı verme, çalışanlara yapmış oldukları işle övünebilmeleri, işini ve işyerini sevebilmeleri için yapılmaya değer bir iş verme, onlara sosyal statünün kazandırılması, kendi yaşam biçimlerine saygılı olunması ve davranması sağlanmalıdır (Genç, 2005: 237; Sezici, 2008: 183). Motivasyonun karmaşık ve bazen anlaşılması güç ilişkiler yumağı olması nedeniyle liderin çalışanları nasıl etkili motive edeceğini çok iyi analiz etmesi ve bu konuda gerekli çabaların ortaya konması çok önemlidir. Her örgütte liderler, çalışanlarına özgü motivasyon tekniklerini kullanarak onların performansı ile örgütün etkinliği ve verimliliğini artırması gerekmektedir.

\section{Sonuç}

Liderin, her şeyden önce çalışanları örgütün amaçları doğrultusunda yönlendirmesi şarttır. Çalışanların örgütsel amaçlar doğrultusunda motivasyonunun sağlanması, liderin en asli görevlerindendir. Çalışanları isteklendirmeye ve örgütte verimli çalışmaya yönelik kişisel ihtiyaçların karşılanması süreci olarak motivasyon sayesinde, liderler ve çalışanlar arasında bir etkileşim başlatılarak ve örgütsel hedefler doğrultusunda işbirliği yapılarak yüksek bir performansa ulaşmak mümkün olabilmektedir.

İyi bir liderlik anlayışıyla örgütte motivasyonun artırılması, çalışanların yaptıkları işin önemli olduğu düşüncesini ön plana çıkarır. Çal1şanlar, sürekli takdir edilmeyi, güven ve saygı duyulmayı, sorumluluk yüklenmeyi, kendine yüklenen görevleri başarı ile yerine getirmeyi isteyen bir psikolojiye sahiplerdir. Fizyolojik ve psikolojik gereksinimler, çalışanları harekete geçirerek doyuma ulaşmak için sürekli çabalamaya zorlar. Çalışma ortamı, çalışanların hem fizyolojik hem de psikolojik açıdan doyuma ulaşmak istediği en önemli yeri oluşturur. 
Çalışma ortamının fiziksel koşulları, çalışma arkadaşları, verilen emek karşılığında alınan ücret, sahip olunan mesleğin saygınlık derecesi, kişinin kendini tatmin arzusu ve en önemlisi de bünyesinde çalıştığ 1 liderin tutumu kişiyi motive eden araçlardandır. Örgütün etkili ve verimli olabilmesi için lider ile çalışanların koordinasyon içinde çalışması gereklidir. Bunun için liderin çalışanları motive edecek teknikleri bilmesi ve uygulaması şarttır. Lider, takipçilerini çok iyi tanımalı ve örgütsel hedeflere ulaşabilmek için onları etkili şekilde motive edebilmelidir. Lider, her şeyden önce kendine güvenmeli, beraber çalıştığ 1 kişilerin görüş ve düşüncelerine çekinmeden başvurabilmeli ve onları daha fazla çalışmaya isteklendirmelidir.

Lider her zaman yeniliğe, yeni fikir ve görüşlere açık olmalı, cesaretli ve düşüncelerinde açık ve net olmalı ve sözünün arkasında durabilmelidir. Çalışanların morallerini en üst seviyede tutabilecek, çalışmaya isteklendirebilecek ve onları tatmin edecek bir ücret verebilmelidir. Gerçi klasik motivasyon tekniği olarak kullanılan ücret her ne kadar motivasyonda etkili olsa da, aslında maddi özendiricilerin yanında personelin psikolojik ihtiyaçlarının da tatmin edilmesi çok önemlidir. Çalışanların doyumu ve bu sayede onların örgüte bağlanması, örgütün performansının kendiliğinden yükselmesini sağlayacaktır. $\mathrm{Bu}$ da liderin örgütte motivasyonu etkili şekilde kullanmasını sağlayacaktır.

\section{Kaynakça}

Adair, John, (2003). Etkili Motivasyon: İnsanlardan En İyi Verimi Nasıl Alabilirsiniz?. İstanbul: Babıali Kültür Yayıncılığı.

Akat, İlker- Budak, Gönül \& Budak, Gülay, (1994). İşletme Yönetimi. İstanbul: Beta Yayınları.

Akçadağ, Sibel \& Özdemir, Ekrem, (2005). «İnsan Kaynakları Kapsamında 4 ve 5 Yıldızlı Otel İşletmelerinde İş Tatmini: İstanbul`da Yapılan Ampirik Bir Çalışma». Kocaeli Üniversitesi Sosyal Bilimler Enstitüsü Dergisi, Cilt: 10, Sayı: 2, s. 167-193. 
Bakan, İsmail \& Büyükbeşe, Tuba, (2010). “Liderlik Türleri” ve “Güç Kaynakları”na İlişkin Mevcut-Gelecek Durum Karşılaştırması: Eğitim Kurumu Yöneticilerinin Algılarına Dayalı Bir Alan Araştırması”, Karamanoğlu Mehmet Bey Üniversitesi Sosyal ve Ekonomik Araştırmalar Dergisi, Cilt: 12, Say1: 19, s. 73-84.

Bateman, Thomas S. \& Zeithaml, Carl P, (1990). Management: Function And Strategy, Richard D. Irwin Inc Publisher.

Baysal, A. Can \& Tekarslan, Erdal, (1996). İşletmeciler İçin Davranış Bilimleri, 2. Baskı, İstanbul: Avcıl Basım-Yayın.

Bolat, Tamer - Seymen, Oya Aytemiz - Bolat, Oya İnci \& Erdem, Barış, (2008). Yönetim ve Organizasyon, Ankara: Detay Yayınları.

Burns, James MacGregor, (1979). “Two Excepts from Leadership”, Educational Leadership, Volume: 36, Issue: 6, pp. 380-383.

Çağlar, İrfan, (2004). "İktisadi ve İdari Bilimler Fakültesi Öğrencileri İle Mühendislik Fakültesi Öğrencilerinin Liderlik Tarzına İlişkin Eğilimlerinin Karşılaştırılmalı Analizi ve Çorum Örneği”, Gazi Üniversitesi Ticaret ve Turizm Eğitim Fakültesi Dergisi, Sayı: 2, Ankara.

Can, Halil, (1979). Organizasyon ve Yönetim, Ankara: Siyasal Kitabevi.

Çelik, Cemile \& Sünbül, Önder, (2008). "Liderlik Algılamalarında Eğitim ve Cinsiyet Faktörü: Mersin İlinde Bir Alan Araştırması”, Süleyman Demirel Üniversitesi İktisadi ve İdari Bilimler Fakültesi Dergisi, Cilt: 13, Sayı: 3, s. 49-66.

Çetin, Nesrin Gökben \& Beceren, Ertan, (2007). "Lider Kişilik: Gandhi”, Süleyman Demirel Üniversitesi Sosyal Bilimler Enstitüsü Dergisi, Y1l: 3, Say1: 5, s. 110-132.

Choi, Jaepil, (2006). "A Motivational Theory of Charismatic Leadership: Envisioning, Empathy, and Empowerment", Journal of Leadership and Organizational Studies, Volume: 13, Issue: 1, Fall, pp. 24-43. Çırpan, Hüseyin, (1999). “Lider mi, Yönetici mi?”, Active Yayınları, Haziran-Temmuz, ftp://79.123.147.210/ sbmyo/Isletme\%20 Becerileri\%20 Makale \% 2015\%20-\%2019\%20Nisan.pdf, (Erişim Tarihi: 21.03.2014). 
Davis, Keith, (1988). İ̧sletmede İnsan Davranışı: Örgütsel Davranış. (Çev: Kemal Tosun - Tomris Somay - Fulya Aykar - Can Baysal - Ömer Sadullah \& Semra Yalçın), 3.Baskı, İstanbul Üniversitesi İşletme Fakültesi İşletme İktisadı Enstitüsü Yayınları.

DeCenzo, David A. \& P. Robbins, Stephen, (1996). Human Resource Management. 5. Edition, John Wiley \& Son, New York.

DeMato, Doris S, (2001). Job Satisfaction Among Elemantary School Counselors In Virginia. For Degree of Ph. D. Blacksburg, Virginia.

Dilts, Robert B, (1996). Visionary Leadership Skills. California: Meta Publications.

Doğan, Selen, (2007). Vizyona Dayalı Liderlik. İstanbul: Kare Yayınları, 2. Baskı.

Efil, İsmail, (2006). Yönetim ve Organizasyon. İstanbul: Alfa Aktüel Yayınları, 8. Bask1.

Erdoğan, İrfan, (2002). Eğitimde Değişim Yönetimi. Ankara: Pegem Akademi Yayıncılık.

Eren, Erol, (1993). Yönetim Psikolojisi. İstanbul: Beta Yayınları, 4. Baskı.

Eren, Erol, (2004). Örgütsel Davranış ve Yönetim Psikolojisi. İstanbul: Beta Yayınları, 8. Baskı.

Eren, Erol, (2000). Örgütsel Davranışve Yönetim Psikolojisi. İstanbul: Beta Yayınları, 6. Baskı.

Eren, Erol, (2003). Yönetim ve Organizasyon. İstanbul: Beta Yayınları, 6. Bask1.

Eroğlu, Feyzullah, (2000). Davranış Bilimleri. İstanbul: Beta Yayınları, 5. Bask1.

Ertürk, Mümin, (2000). İşletmelerde Yönetim ve Organizasyon. İstanbul: Beta Yayınları, 6. Baskı.

Fındıkçı, İlhami, (2009). Bir Gönül Yolculuğu Hizmetkâr Liderlik, İstanbul: Alfa Yayınları.

Genç, Nurullah, (2005). Yönetim ve Organizasyon: Çağdaş Sistemler ve Yaklaşımlar, Ankara: Seçkin Yayınları, 2. Baskı. 
Gürüz, Demet \& Gürel, Emel, (2006). Yönetim ve Organizasyon, Ankara: Nobel Yayınları.

Güney, Salih, (1997). "Yönetici ve Yönetilen Açısından Disiplin ve Moral”, 21. Yüzylla Liderlik Sempozyumu-5-6 Haziran, İstanbul: Deniz Harp Okulu.

Hageman, Gisela, (1997). Motivasyon El Kitabı, Bireysel Yatırım Dizisi, İstanbul: Rota Yayınları.

Kark, Ronit \& Dijk, Dina Van, (2007). "Motivation to Lead, Motivation to Follow: the Role of the Self-Regulatory Focus in Leadership Processes", Academy of Management Review, Vol. 32, No. 2, pp. 500-528.

Koçel, Tamer. (2003), Isşletme Yöneticiliği, İstanbul: Beta Yayınları, 9. Baskı.

Koçel, Tamer. (2001), İşletme Yöneticiliği, İstanbul: Beta Yayınevi.

Luthans, Freud. (1992), Organizational Behavior, 6. Edition, NewYork: McGrawHill Inc.

Müller, Günter F. - Georgianna, Sibylle - Engel, Karin Schermelleh, (2003). "Super-Leadership and Work Enjoyment: Direct and Moderated Influences", Psychological Reports: Employment Psychology \& Marketing, 113, 3, pp. 804-821.

Newstrom, John W. \& Davis, Keith, (1993). Organizational Behavior: Human Behavior At Work, 9. Edition, NewYork: McGraw Hill Inc.

Oral, Saime, (1999). Otel İşletmeciliği ve Otel İsletmelerinde Verimlilik Analizleri, İzmir: Kanyılmaz Matbaası.

Purcell, Lori Elizabeth, (2003). Factors That Lead To Job Satisfaction And Dissatisfaction Of County Extension Agent In Georgia, The University Of Georgia.

Robbins, Stephen P., (1996). Organizational Behavior: Concepts, Controversies, Applications, Seventh Edition, Englewood Cliffs, NJ: Prentice Hall International Inc.

Rost, Joseph C., (1993). Leadership for the Twenty-First Century. Praeger New York. 
Sargut, A. Selami, (2001). Kültürler Arası Farklılaşma ve Yönetim. İstanbul: İmge Yayınları.

Serinkan, Celalettin, (2008). Liderlik ve Motivasyon İlişkisi. 1. Baskı, Ankara: Nobel Yayınları.

Sezici, Emre, (2008). "Motivasyon”, İşletme Becerileri Grup Çalışması. Kenan Mehmet Ekici- Tarık Zeki Şahım (Ed.), Ankara: Savaş Yayınlar1, s. 169-183.

Şimşek, M. Şerif - Akgemici, Tahir \& Çelik, Adnan, (1998). Davranış Bilimlerine Girişve Örgütlerde Davranış. Ankara: Nobel Yayınları.

Türkmen, İsmail, (1999). Yönetsel Zaman ve Yetki Devri Açısından Yönetimde Verimlilik. Ankara: Milli Prodüktivite Yayınları, Yayın No: 519.

Ünlü, Sezen - Eroğlu, Erhan - Gökdağ, Rüçhan - Ergüven, M. Sinan, (2013). İş ve Yaşamda Motivasyon. Yavuz Tuna (Ed.), Eskişehir: Anadolu Üniversitesi Yayınları.

Vecchio, Robert P., (1991). Organizational Behavior. London: Dryden Press.

Wadsworth, Walter J., (1999). Atak Yöneticinin Liderlik Rehberi. (Çev: E. Sabri Yarmalı), İstanbul: Hayat Yayıncılık.

Werner, Isabel, (1993). Liderlik ve Yönetim. (Çeviren: Vedat Üner), İstanbul: Rota Yayınları.

Wiley, Carolyn, (1997). "What Motivates Employees According To Over 40 Years Of Motivation Surveys”, International Journal of Manpower, Volume: 18, Issue: 3, pp. 263-280.

Yeo, Roland K., (2006). "Developing Tomorrow's Leaders: Why Their Worldviews of Today Matter ?", Industrial and Comercial Trainning, Vol. 38, pp. 63-69.

Yukl, A.Gary, (1991). Leadership in Organizations, New Jersey: Prentice Hall.

Yüksel, Öznur, (2000) İnsan Kaynakları Yönetimi. Ankara: Gazi Kitapevi.

Yüksel, Robert B., (1996). Visionary Leadership Skills, California: Meta Publications. 
Abstract:-Leadership and Motivation: A Theoretical EvaluationLeadership in nowadays is accepted as the ability to influence and direct people consciously for achieving specific goals and objectives. A good leader does not only guide organization members to reach professional success, but also he/she plays a role in giving them confidence, using the power of persuasion and mostly motivating them. Therefore, a modern leader should contribute by being farsighted, effective and efficient, behaving ethically and morally and besides increasing employees' self-confidence and development by keeping channels of communication available. In this extent, this work aims to investigate the concepts of "leadership" and "motivation" in organization in theoretical terms and explicate the relationship between the two. In this study, the definition, types and approach of leadership are initially explained under the heading "the concept of leadership and its features" and then the description, types and theories of motivation are explained under the title of "the concept of motivation and its features".

Key words: Leader, Leadership, Approaches of leadership, Motivation, Motivation theories. 
